\title{
Warming constrains bacterial community responses to nutrient inputs in a southern, but not northern, maritime Antarctic soil
}

Paul G. Dennis ${ }^{\mathrm{a}, \dagger}$, Kevin K. Newsham ${ }^{\mathrm{b}}$, Steven P. Rushton ${ }^{\mathrm{c}}$, Victoria J. Ord ${ }^{\mathrm{c}}$, Anthony G.

5 O’Donnell ${ }^{\mathrm{c}, \mathrm{d}}$, David W. Hopkins ${ }^{\mathrm{a}, \mathrm{e}, *}$

${ }^{a}$ School of Biological and Environmental Sciences, University of Stirling, Stirling, FK9 4LA, UK, ${ }^{b}$ Ecosystems Programme, British Antarctic Survey, Madingley Road, Cambridge, CB3 OET, UK; ${ }^{c}$ School of Biology, Newcastle University, Newcastle upon Tyne, NE1 7RU, UK;

${ }^{d}$ University of Western Australia, 35 Stirling Highway, Crawley WA 6009, Australia; ${ }^{e}$ School of Life Sciences, Heriot-Watt University, Riccarton, Edinburgh, EH14 4AS, UK

${ }^{\dagger}$ Current address: Australian Centre for Ecogenomics, and Advanced Water Management Centre, The University of Queensland, Brisbane, QLD 4072, Australia

15

* Corresponding author. Tel.: + 440131451 3452. E-mail address:

david.hopkins@hw.ac.uk (D.W. Hopkins). 


\section{Abstract}

We investigated the effects of increased soil temperature, water and nutrient availability on soil bacterial communities at Wynn Knolls on Signy Island $\left(60^{\circ} \mathrm{S}\right)$ in the northern maritime

25 Antarctic and at Mars Oasis $\left(71^{\circ} \mathrm{S}\right)$ in the southern maritime Antarctic. After 10-12 months, analyses of the concentrations of ester linked fatty acids (ELFAs) in soil indicated that bacterial communities responded positively to single applications of substrates at both locations, with $20 \%$ and $49 \%$ increases in total Gram positive and Gram negative bacterial markers, respectively, in response to the application of tryptic soy broth (TSB; a complex

30 substrate containing organic carbon and nitrogen, plus other nutrient elements) at Wynn Knolls, and 120\% and 44\% increases in Gram positive bacterial markers at Mars Oasis in response to the application of TSB and the amino acid glycine (a relatively simple source of organic carbon and nitrogen), respectively. Responses to the warming treatment were not detected at Wynn Knolls, where open top chambers (OTCs) increased mean monthly soil temperatures by up to $0.7^{\circ} \mathrm{C}$, but at Mars Oasis, where OTCs increased monthly soil temperatures by up to $2.4{ }^{\circ} \mathrm{C}$, warming led to $41 \%$ and $46 \%$ reductions in the concentrations of Gram positive bacterial markers in soil to which glycine and TSB had been applied, respectively. Warming also led to 55\% and 51\% reductions in the ratio of Gram positive to Gram negative markers in soils at Mars Oasis to which glycine and TSB had been applied.

40 These data suggest that warming may constrain the responses of bacterial communities to carbon and nitrogen inputs arising from dead plant matter entering maritime Antarctic soils in future decades.

Keywords: Antarctica, climate change, Gram negative bacteria, Gram positive bacteria, nutrient input, open top chambers (OTCs), substrate amendments, warming, water application 


\section{Introduction}

Mean annual air temperatures in the maritime Antarctic, particularly along the

western Antarctic Peninsula, have risen at rates of up to $0.4^{\circ} \mathrm{C}$ decade $^{-1}$ over the past $50-100$ years (Adams et al., 2009), which is approximately double the rate at which global mean surface temperature has increased over the last 30 years $\left(c .0 .2^{\circ} \mathrm{C}\right.$ decade ${ }^{-1}$; Hansen et al., 2006). The warming of maritime Antarctic terrestrial ecosystems is having widespread effects on the physical environment: along with the collapse of ice shelves and the retreat of glaciers, changes to precipitation patterns have occurred, with increases in snow accumulation having been recorded in recent decades (Thomas et al., 2008; Adams et al., 2009). In addition to these changes to the physical environment, the warming of maritime Antarctic terrestrial ecosystems is also altering the cover of plant species. For example, the population sizes of Deschampsia antarctica and Colobanthus quitensis, the two native Antarctic higher plant species, increased by 7-26 fold between the mid 1950s and early 1990s (Fowbert and Smith, 1994; Smith, 1994), and a new southern limit for flowering plants in Antarctica has recently been established (Convey et al., 2011). The expansion of maritime Antarctic plant populations over future decades is likely to enhance and alter nutrient inputs to soils (Hill et al., 2011), with the input of carbon and nitrogen to these soils most probably leading to significant increases in soil microbial biomass (Davey and Rothery, 1992; Malosso et al., 2005). Similar increases in nutrient inputs from microbial and cryptogam sources (via photosynthesis and nitrogen fixation) have also been postulated for dry valleys soils in continental Antarctica (Novis et al., 2007; Hopkins et al., 2008). These predictions are supported by studies showing larger microbial biomass in vegetated than in non-vegetated maritime Antarctic soils (Yergeau et al., 2007a).

Warming also influences the size and composition of bacterial communities in maritime Antarctic soils. For example, the deployment of screens over soil at Signy Island in 
the South Orkney Islands increased the abundances of Cyanobacteria in soil by 2-17 fold, with substantial increases in the biomass of Phormidium and Nostoc spp. in warmed soils

75 (Wynn-Williams, 1996). Recently, it has been shown that bacteria are more frequent in vegetated soils that have been passively warmed with open top chambers (OTCs) at two sites in the maritime Antarctic, and that warming increases the ratio of Alphaproteobacteria to Acidobacteria (Yergeau et al., 2012). At present, however, these are the only data on soil bacterial responses to warming in natural maritime Antarctic environments, and, importantly, nothing is known of the combined effects of warming and nutrient inputs on the bacterial communities of maritime Antarctic soils. Given that soil bacteria are pivotal to ecosystem processes, such as the mineralisation of nutrients from dead organic matter, the current lack of data on the responses of these microbes to warming and nutrient input in the region represents a significant gap in knowledge.

Here we report the results of an experiment designed to test the hypothesis that warming, in combination with either nutrient input or water application, would influence Antarctic soil bacterial communities. The study was undertaken at two sites with different climates, one on Signy Island in the northern maritime Antarctic, and the other on Alexander Island in the southern maritime Antarctic. Both of the locations studied have warmed in recent decades: air temperature at Signy Island increased by $1{ }^{\circ} \mathrm{C}$ between 1950 and 1990 (Quayle et al., 2002) and surface temperatures at a site $240 \mathrm{~km}$ to the south of Mars Oasis are estimated to have increased by $2.7^{\circ} \mathrm{C}$ between the mid 1940s and the late 2000s (Thomas et al., 2009). We used OTCs to warm soil to temperatures that are predicted to be reached during the next two to five decades at either location, given these current rates of warming 95 (Adams et al., 2009). 


\section{Materials \& methods}

\subsection{Site descriptions}

The experiment was established at Wynn Knolls (60 $41^{\prime} 56^{\prime \prime} \mathrm{S}, 45^{\circ} 38^{\prime} 10^{\prime}$ ' W) on

100 Signy Island in the South Orkney Islands and at Mars Oasis ( $71^{\circ} 52^{\prime} 42^{\prime \prime} \mathrm{S}, 68^{\circ} 15^{\prime} 00^{\prime}$ ' W) on south-eastern Alexander Island in the southern maritime Antarctic (Fig. 1). Wynn Knolls is situated at $c .500 \mathrm{~m}$ from the western shoreline of Signy Island at an altitude of $199 \mathrm{~m}$ above sea level. The island has an oceanic climate, characterised by dense cloud cover during the austral summer (7.2 - 7.4 oktas; Collins et al., 1975). Precipitation in the northern maritime Antarctic, where Signy Island is located, varies between $350 \mathrm{~mm}$ and $500 \mathrm{~mm}$ water equivalents per annum, with much falling as rain in the austral summer (Smith, 1984). Soils on the island are derived from schists, amphibolites and marbles (Collins et al., 1975). The more southerly site, Mars Oasis, is formed from a contact moraine between the George VI ice shelf and the south-eastern coast of Alexander Island. The oasis, consisting of areas of till,

110 fluvial and lacustrine sediments (Sugden and Clapperton, 1981), with streams and ponds forming during the austral summer, is located at an altitude of $20 \mathrm{~m}$ above sea level. Soil at the site is derived from the sandstones and mudstones of Two Step Cliffs massif. The western Antarctic Peninsula, and in particular its southern reaches, have a relatively continental climate, with frequent periods of cloudless skies during the summer. Precipitation in the

115 southern maritime Antarctic is $c .350 \mathrm{~mm}$ water equivalents per annum, most of which falls as snow (Smith, 1984). The soils at Wynn Knolls and Mars Oasis had similar chemical properties, with mean $( \pm$ SEM) $\mathrm{pH}$ values of $7.5 \pm 0.15$ and $7.3 \pm 0.12$, electrical conductivities of $29.4 \pm 2.9 \mu \mathrm{S}$ and $31.9 \pm 2.7 \mu \mathrm{S}, \mathrm{NO}_{3}{ }^{-}-\mathrm{N}$ concentrations of $0.033 \pm 0.019$ $\mathrm{mg} \mathrm{kg}{ }^{-1}$ and $0.007 \pm 0.007 \mathrm{mg} \mathrm{kg}^{-1}$, and $\mathrm{NH}_{4}{ }^{+}-\mathrm{N}$ concentrations of $0.138 \pm 0.065 \mathrm{mg} \mathrm{kg}^{-1}$ and $0.095 \pm 0.015 \mathrm{mg} \mathrm{kg}^{-1}$, respectively (Dennis et al., 2012). The concentrations of both total organic carbon and total nitrogen in the soils were very small, with organic carbon 
concentrations of $0.140 \pm 0.010 \%$ and $0.260 \pm 0.020 \%$, and nitrogen concentrations of 0.038 $\pm 0.004 \%$ and $0.020 \pm 0.002 \%$ in the two soils, respectively (Dennis et al., 2012).

\subsection{Manipulation experiment and sampling}

Three treatments were applied at each site in factorial combination. Soil was warmed using OTCs, water was applied to soil to simulate short-term changes in moisture availability arising from melting snow and ice, and growth substrates were added to alter carbon and nitrogen availability to soil microbes. The addition of the substrates broadly simulated

130 increases in soil nutrients associated with organic inputs from algae and cyanobacteria, in a way directly analogous to a corresponding experiment in the dry valleys region of continental Antarctica (Hopkins et al., 2008). In order to apply these treatments, 64 circular plots of $1 \mathrm{~m}$ diameter were established at each site within a $17 \mathrm{~m} \times 17 \mathrm{~m}$ area that was devoid of vegetation. Thirty-two of the plots were covered with conical clear polycarbonate OTCs of 1

135 m diameter (see Fig. 1b in Marion et al., 1997). The moisture content of the soil in 16 of the chambered plots and in 16 of the control plots was adjusted to $100 \%$ of water-holding capacity in the surface $5 \mathrm{~cm}$ of soil using water purified with ion exchange columns (Fistreem, UK). For each temperature-water combination, four replicate plots were each either non-amended or were amended with glucose, glycine or powdered tryptic soy broth

140 (Difco, USA), at a rate of $10 \mathrm{mg} \mathrm{C} \mathrm{g}^{-1} \mathrm{dwt}$ soil (Hopkins et al., 2008), which was mixed into the soil surface to $c .20 \mathrm{~mm}$ depth. The experimental layout resulted in 16 temperature-watersubstrate combinations, each replicated four times in a randomised design at each site. Soil temperatures (depth $c .10-50 \mathrm{~mm}$ ) were recorded at each site in three randomly-selected chambered and three randomly-selected control plots using TinyTag Plus 2 TGP-4017

145 loggers (Gemini Data Loggers Ltd., UK). The plots at Mars Oasis were established in November 2007 and those at Wynn Knolls in January 2008. Soils were collected from the 64 
plots at each site after 10 and 12 months, respectively, by filling $50 \mathrm{ml}$ clean plastic tubes with soil (depth $c$. 0-20 mm), which were then frozen until analysis.

The analysis of ELFAs (ester-linked fatty acids) limited to known microbial fatty acids allows the rapid fingerprinting of lipids in the soil of microbial origin (Drijber et al., 2000; Steger et al., 2003; Hinojosa et al., 2005). ELFAs were extracted from soil (10 g) "spiked" with a $3 \mu \mathrm{g}$ aliquot of the ELFA 23:0 as an internal standard, and were then derivatised using the method of Schutter and Dick (2000) and analysed by gas chromatography (GC). The GC analyses were conducted on an Agilent Technologies 6890N Network GC system with a flame ionization detector and an Agilent HP-5 column (Agilent Technologies, UK) with helium as the carrier gas. The temperature programmed resolution of individual esters was carried out at $160{ }^{\circ} \mathrm{C}$ for $2 \mathrm{~min}, 160-270{ }^{\circ} \mathrm{C}$ at $4{ }^{\circ} \mathrm{C} \mathrm{min}{ }^{-1}$, and then at $270{ }^{\circ} \mathrm{C}$ for $10 \mathrm{~min}$. ELFAs were identified by comparing retention times with commercial (bacterial acid methyl esters mixture; Supelco, USA) and in-house standards and were quantified by relating the area of individual peaks to that of the internal standard.

\subsection{Statistical analyses}

Bacterial biomass was estimated by summing the ELFAs (expressed as nmol fatty acid $\mathrm{g}^{-1} \mathrm{dwt}$ soil) indicative of Gram positive bacteria (viz., i15:0, a15:0, br16:0, i16:0, br17:0, 10Me16:0, i17:0, a17:0, br18:0, 10Me17:0, 10Me18:0 and 19:1; Lechevalier and Lechevalier, 1988; O’Leary and Wilkinson, 1988) and Gram negative bacteria (viz., 16:109c,

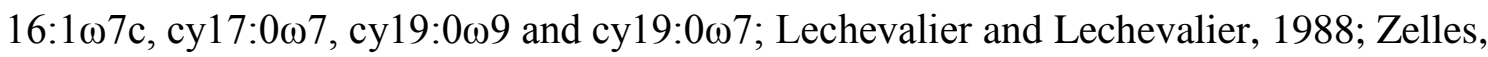
1999). The ratio of Gram positive to Gram negative markers was also calculated. General Linear Models and one-way ANOVA were used to determine the effects of OTCs, water and 
substrate treatments on the concentrations of ELFAs in the MINITAB 15 package. The effects of the treatments on the concentrations of individual ELFAs were analysed separately when treatment effects were identified on the concentrations of total Gram positive or Gram 175 negative markers.

\section{Results}

\subsection{Effects of OTCs on soil temperature and frequency of freeze-thaw cycles}

The deployment of OTCs at Wynn Knolls on Signy Island led to minimum, mean and

180 maximum increases in monthly soil temperatures of $0.3{ }^{\circ} \mathrm{C}, 0.6^{\circ} \mathrm{C}$ and $0.7^{\circ} \mathrm{C}$, respectively, relative to controls (Fig. 2a), whereas at Mars Oasis on Alexander Island, OTC deployment resulted in larger increases in soil temperatures, with minimum, mean and maximum increases in monthly soil temperatures of $0.6^{\circ} \mathrm{C}, 1.3^{\circ} \mathrm{C}$ and $2.4^{\circ} \mathrm{C}$, respectively (Fig. 2b). The largest increases in monthly soil temperatures arising from OTC deployment at Mars

185 Oasis usually occurred between November and February (Fig. 2b), when the site was free of snow. Although mean $( \pm$ SEM) summer (Dec - Feb) soil temperatures in control plots did not differ between Mars Oasis and Wynn Knolls $\left(3.6 \pm 1.1^{\circ} \mathrm{C}\right.$ and $1.9 \pm 0.4{ }^{\circ} \mathrm{C}$, respectively; $F_{1,7}$ $=2.05, P>0.05)$, soil temperatures were significantly lower at Mars Oasis than at Wynn Knolls during the other months of the year $\left(-10.3 \pm 1.4{ }^{\circ} \mathrm{C}\right.$ and $-4.4 \pm 1.2{ }^{\circ} \mathrm{C}$, respectively; $\left.F_{1,15}=10.42, P<0.01\right)$.

No effects of OTCs were recorded on the number of monthly freeze-thaw cycles at Wynn Knolls, where there were $0.3-7$ cycles month ${ }^{-1}$ in control plots when soil was not permanently frozen (Oct-Apr; data not shown). In contrast, OTC deployment at Mars Oasis significantly decreased the mean $( \pm$ SEM) number of freeze-thaw events in December 2007 and 2008 from $11.9 \pm 1.4$ to $3.3 \pm 1.3$ cycles and from $10.8 \pm 1.2$ to $6.1 \pm 1.3$ cycles, respectively, and in January 2008 from $5.8 \pm 1.4$ to $0.1 \pm 1.7$ cycles (all $P<0.05$; data not 
shown). The mean number of freeze-thaw cycles month ${ }^{-1}$ in control plots during months in which the soil was not permanently frozen was significantly higher at Mars Oasis than it was at Wynn Knolls $\left(11.0 \pm 2.8\right.$ and $3.8 \pm 0.8$, respectively; $\left.F_{1,13}=7.06, P<0.05\right)$.

\subsection{Between-site differences}

There were apparent differences in the bacterial biomass between the two sites, as indicated by the concentrations of bacterial markers in the soils. The concentrations of Gram positive and Gram negative bacterial markers were $76 \%$ and $85 \%$ lower at Mars Oasis than at Wynn Knolls, respectively (Fig. 3a, b). However, Gram positive markers were relatively more frequent at Mars Oasis: the ratio of Gram positive to Gram negative markers was $54 \%$ greater at this site than it was at Wynn Knolls (Fig. 3c).

\subsection{Responses to substrate amendments and water addition}

The addition of substrates to soil had significant effects on bacterial markers.

Substrate amendments affected the amount of both Gram positive and Gram negative markers at Wynn Knolls (Table 1), with 20\% and 49\% increases, respectively, in the concentrations of ELFAs indicative of Gram positive and Gram negative forms in response to the application of TSB to soil at this site, relative to non-amended controls (Fig. 4a, b). In soil to which TSB

215 had been applied, the increases in Gram positive markers were associated with greater concentrations of the ELFAs a15:0 and a17:0 (Fig. 4a, inset), and the increases in Gram negative markers were associated with a greater concentration of $16: 1 \omega 7 \mathrm{c}$ (Fig. 4b, inset). The addition of substrates to soil did not affect the ratio of Gram positive to Gram negative markers at Wynn Knolls (Fig. 4c). Significant effects of substrate amendments were also

220 detected on the concentrations of Gram positive markers at Mars Oasis (Table 1). At this site, the addition of glycine and TSB to soil led to $44 \%$ and $120 \%$ increases in the concentrations 
of ELFAs indicative of Gram positive bacteria, relative to controls (Fig. 4d). These increases were associated with greater concentrations of a15:0 and a17:0 in soil to which glycine and TSB had been applied (Fig. 4d, inset). The concentrations of ELFAs indicative of Gram negative bacteria remained unaffected by the substrate amendments at Mars Oasis (Fig. 4e), but there were $106 \%$ and $58 \%$ increases in the ratio of Gram positive to Gram negative markers after glycine and TSB had been applied to soil at this site, respectively, relative to non-amended soil (Fig. 4f).

The addition of water had no effect on the concentrations of ELFAs in soil at either

230 Wynn Knolls or Mars Oasis, and there were no interactive effects of water with OTCs or substrates on ELFA concentrations at either site (Table 1).

\subsection{Responses to OTCs}

Although no main or interactive effects of OTCs were recorded on ELFA profiles at Wynn

235 Knolls, a significant main effect of OTCs, and a significant substrate $\times$ OTC interaction term, was detected on ELFA concentrations in soil at Mars Oasis (Table 1). There were no effects of OTCs on Gram positive markers or the ratio of Gram positive to Gram negative markers in control (non-amended) soil or soil to which glucose had been applied at Mars Oasis, with the only significant effects of OTCs being recorded in soils to which glycine and TSB had been

240 applied (Fig. 5), accounting for the significant OTC $\times$ substrate interaction term. In soil to which glycine and TSB had been applied, OTCs led to $41 \%$ and $46 \%$ reductions in the concentrations of ELFAs indicative of Gram positive markers, respectively (Fig. 5c, d). In both cases, these reductions were associated with lower concentrations of the ELFAs a15:0 and a17:0 in chambered, compared with control, soil (Fig. 5c, d, insets). No significant

245 differences were recorded between the mean ( \pm SEM) concentrations of ELFAs indicative of Gram positive bacteria in warmed soil to which glycine and TSB had been applied (5.02 \pm 
0.82 and $5.79 \pm 1.26 \mathrm{nmol} \mathrm{g}^{-1} \mathrm{dwt}$ soil, respectively; Fig. $\left.5 \mathrm{c}, \mathrm{d}\right)$ and those in warmed soil to which no substrate had been applied $\left(3.34 \pm 0.30 \mathrm{nmol} \mathrm{g}{ }^{-1}\right.$ dwt soil; Fig. $5 \mathrm{a} ; F_{1,15}=3.76$ and 3.64, respectively, both $P>0.05$ ). The combination of warming and substrate amendment also influenced the relative abundance of Gram positive markers: in soil to which glycine and TSB had been applied, OTCs reduced the ratio of Gram positive to Gram negative markers by $55 \%$ and $51 \%$, relative to controls (Fig. $5 \mathrm{~g}, \mathrm{~h}$ ). As with the concentrations of Gram positive markers, the mean $( \pm S E M)$ ratios of Gram positive to Gram negative markers in warmed soil to which glycine and TSB had been added $(1.57 \pm 0.17$ and $1.27 \pm 0.22$; respectively, Fig. 5g, h) were not significantly different from the ratio recorded in warmed soil to which no substrate had been applied (1.25 \pm 0.14 ; Fig. 5 e; $F_{1,15}=2.20$ and 0.01 , respectively, both $P>0.05)$.

\section{Discussion}

It is usually assumed that environmental warming will have positive effects on the biota that inhabit the cold and arid soils of the Antarctic (Convey and Smith, 2006; Convey, 2011). This view is supported by data from warming experiments on Eubacteria and Cyanobacteria, and long-term observations of plant populations in the natural environment (Fowbert and Smith, 1994; Smith, 1994; Wynn-Williams, 1996; Yergeau et al., 2012).

265 However, our study does not support this assumption: here, we applied a warming treatment that was consistent with two- to five-decadal changes in temperature in maritime Antarctic ecosystems at Signy Island ( $1{ }^{\circ} \mathrm{C}$ between 1950 and 1990; Quayle et al., 2002) and close to Alexander Island $\left(2.7^{\circ} \mathrm{C}\right.$ between the 1940s and 2000s; Thomas et al., 2009), and found no significant effect of the treatment on the biomass of bacteria in non-amended soils at either location after one year. However, we cannot discount the possibility that further years of 
treatment might lead to positive effects of warming on bacterial biomass in soils to which substrates are not added.

Owing to the frequent occurrence of cloudless skies in the southern maritime Antarctic, Mars Oasis received more thermal input than Wynn Knolls during summer, and 275 the warming effect of the OTCs was consequently amplified at this more southerly site. Here, when substrates were applied to warmed soil in the form of an amino acid (glycine) or a complex mixture of organic carbon, nitrogen and other elements (TSB), there were substantial reductions in the concentrations of Gram positive bacterial markers. This confirmed our hypothesis that a combination of warming and nutrient input would influence

280 soil bacterial communities. These reductions constrained the response of the soil bacterial community to warming, because the concentration of total Gram positive bacterial markers in warmed soil that received glycine or TSB was no greater than in warmed soil that received no nutrient input. The changes were associated with reductions in chambered soil in the concentrations of the ELFAs a15:0 and a17:0, which are frequent in Actinobacteria such as

285 Arthrobacter and in aerobic endospore-forming bacteria (Haack et al., 1994; Kieft et al., 1994). These data, along with our observation that the ratio of Gram positive to Gram negative markers declined when glycine- and TSB-amended soil at Mars Oasis was warmed, support previous data indicating that warming alters the composition of Antarctic soil bacterial communities (Wynn-Williams, 1996; Yergeau et al., 2012).

The short-term increase in soil moisture applied in the current study had no apparent effects on soil bacterial communities, probably reflecting the 10- and 12-month periods between the single applications of water and sampling at each site. Similarly, annual applications of water to soils of the dry valleys in the continental Antarctic have no effects on the abundances of nematodes (Simmons et al., 2009), although rapid freezing and sublimation often limits the residence time of liquid water in these soils (Hopkins et al., 
2006a). More frequent water application would most probably have had measurable effects on soil bacterial biomass, since bacteria are more abundant in Antarctic soils that contain more liquid water (Wynn-Williams, 1996; Harris and Tibbles, 1997). However, water availability is not considered to be a major factor controlling the composition of maritime

300 Antarctic soil bacterial communities, and so substantial changes to community composition associated with increased water availability are unlikely (Newsham et al., 2010).

In contrast to the lack of response to water application, the soil bacterial communities at Wynn Knolls and Mars Oasis responded positively to both glycine and TSB amendments, confirming the view that microbial growth and activity is limited by carbon, and in particular,

305 nitrogen inputs in both maritime (Davey and Rothery, 1992; Malosso et al., 2005) and continental (Hopkins et al., 2006b, 2008; Sparrow et al., 2011) Antarctic soils. As with the responses to the warming treatment, these increases were associated with greater concentrations of the Gram positive markers a15:0 and a17:0, but were also associated with increased concentrations of the general Gram negative marker $16: 1 \omega 7 \mathrm{c}$ in TSB-amended soil

310 at Wynn Knolls. The relative frequency of Gram positive markers in Mars Oasis soil also changed in response to carbon and nitrogen inputs: when glycine and TSB were applied to soil at this site, the ratio of Gram positive to Gram negative markers increased, corroborating data from studies on subarctic heath soils, in which this ratio responded positively to inorganic nutrient (N, P and K) inputs (Schmidt et al., 2000; Rinnan et al., 2007). The greater

315 ratio of Gram positive to Gram negative markers observed in nutrient-amended subarctic heath soils has been attributed to changes mediated by the plant community (Rinnan et al., 2007), but this cannot explain the effects reported here in non-vegetated soils. Rather, we attribute the increase in the relative frequency of Gram positive markers following substrate amendment to the low concentration of nitrogen in Mars Oasis soil, which, on the addition of 320 organic carbon, probably results in increased nitrogen demand of Gram positive bacteria. 
Arctic studies indicate comparatively slow responses of soil microbial communities to warming and inorganic nutrient additions in the natural environment, with up to 15 years required for microbial community composition to respond to these treatments (Rinnan et al., 2007; Deslippe et al., 2011). In contrast, the responses to the warming and substrate treatments recorded here were relatively rapid: glycine or TSB amendments led to substantial increases in the concentrations of bacterial markers in one year or less. The discrepancy between the observations from Arctic and Antarctic studies is probably associated with plant cover: plants were absent from the soils studied here, allowing clear treatment effects of warming and substrate amendments on soil bacteria to be identified. In contrast, the majority

330 of the soils that are experimentally warmed in the Arctic are vegetated, with higher plant cover, notably that of deciduous shrubs, responding to warming and $\mathrm{N}$ or $\mathrm{P}$ fertilization after 2-6 years and 6-15 years of treatment, respectively (Shaver et al., 2001; Walker et al., 2006; Wookey et al., 2009). These increases alter the composition of rhizosphere- and rootinhabiting microbes, but the effects only manifest themselves after 15-18 years of treatment

335 (Rinnan et al., 2007; Deslippe et al., 2011).

The harsher environment at Mars Oasis, with its lower winter temperatures and greater frequency of freeze-thaw cycles during summer, had apparent effects on soil bacterial biomass, with smaller ELFA concentrations indicative of both Gram positive and Gram negative bacteria at this site compared with Wynn Knolls. This is in broad agreement with

340 studies showing reduced soil bacterial biomass at more southerly locations in the maritime Antarctic (Yergeau et al., 2007a). However, we found that the ratio of Gram positive to Gram negative markers was greater at Mars Oasis, corroborating the view that Gram positive bacteria, which possess thick, interlinked peptidoglycan cell walls, are more frequent in extreme soils (Schimel et al., 2007). For example, Gram positive, and in particular 345 endospore-forming, bacteria are frequent in soil at Mars Oasis, where the analysis of clone 
libraries indicates that members of the order Actinomycetales are the most frequent bacteria in soil close to the area where the OTCs were deployed (Newsham et al., 2010), and that the frequency of Actinobacteria in soil is approximately double that of a fellfield soil on Signy Island (Yergeau et al., 2007b). More widely, analyses of clone libraries indicate that the most 350 frequent bacteria in soils from three sites in the dry valleys in Victoria Land are the Actinobacteria (Smith et al., 2006).

Using rates of respiration of soil micro-organisms at different temperatures for a range of Arctic soils (Mikan et al., 2002), and the current temperature data (Fig. 2), we estimate the approximate cumulative annual respiration to be about 3.5 times greater at Wynn Knolls than

355 at Mars Oasis, with the warming treatments increasing annual respiration by $10 \%$ and $50 \%$ at Wynn Knolls and Mars Oasis, respectively. These estimates suggest that although microbial respiration (activity) was greater at Wynn Knolls (the more maritime, wetter and warmer site) than at Mars Oasis, the potential for microbial responses to warming was greater at Mars Oasis than it was at Wynn Knolls, relative to the unwarmed control. This suggests that factors

360 such as liquid water availability or nutrient availability are more likely constraints to microbial responses at the more southerly site. Comparable effects of soil water content on microbial activity were observed in an experiment in an extreme cold and dry site in the dry valleys (Sparrow et al., 2011).

What mechanisms might explain the reductions reported here in bacterial biomass in 365 warmed, substrate-amended soils? One possibility is that the amelioration of the soil environment caused by OTC deployment at Mars Oasis may have increased the frequencies of bacterivorous nematodes in soil. However, this is unlikely, given the very low densities of nematodes in soil at the location where the OTCs were deployed (c. 12 individuals $\mathrm{kg}^{-1}$ soil; Convey and Wynn-Williams, 2002) and the finding that OTC deployment decreases the abundance of a microbial-feeding nematode species by $42 \%$ in dry valleys soils (Simmons et 
al., 2009). A further possibility is that the increased temperature of soil in OTCs may directly inhibit the growth of the bacterial community. Again, this is unlikely, given the tendency for microbes in soils exposed to wide seasonal fluctuations in temperature, such as those at Mars Oasis, to be psychrotrophs, which have optimum growth temperatures of $>15{ }^{\circ} \mathrm{C}$ (Russell, 375 1990). A more plausible explanation is that the elevated soil temperatures within OTCs decreased soil water matrix potential, which limited the diffusion of the substrates to metabolically active cells and decreased bacterial growth rates in soil (Zak et al., 1999). Whether or not such effects occur when senescent plant material enters southern maritime Antarctic soils is at present an open question, but is one that urgently needs to be addressed.

\section{Acknowledgements}

Funding was supplied by the Natural Environment Research Council through the Antarctic Funding Initiative (AFI 7/05; NE/D00893X/1). Logistical support was provided by the British Antarctic Survey’s Operations Group and Air Unit, and Phil Coates, Mike Dunn, Paul

385 Torode, Matt Jobson, Daniel Prunier, Adam Clark and Dickie Hall assisted with fieldwork. Jenni Dungait assisted with the interpretation of ELFA data, Etienne Yergeau provided preprints of papers and anonymous referees supplied helpful comments on a previous version of the manuscript. All are gratefully acknowledged.

\section{References}

Adams, B., and 64 others, 2009. The Instrumental Period. In: Turner, J., Bindschadler, R., Convey, P., di Prisco, G., Fahrbach, E., Gutt, J., Hodgson, D., Mayewski P., Summerhayes, C. (Eds.), Antarctic Climate Change and the Environment. Scientific Committee on Antarctic 395 Research, Scott Polar Research Institute, Cambridge, UK, pp. 183-298. 
Collins, N.J., Baker, J.H., Tilbrook, P.J., 1975. Signy Island, Maritime Antarctic. In:

Rosswall, T., Heal, O.W. (Eds.), Structure and Function of Tundra Ecosystems. Ecological Bulletins 20, 345-374.

400

Convey, P. 2011. Antarctic terrestrial biodiversity in a changing world. Polar Biology 34, $1629-1641$.

Convey, P., Hopkins, D.W., Roberts, S.J., Tyler, A.N., 2011. Global southern limit of 405 flowering plants and moss peat accumulation. Polar Research 30, 8929.

Convey, P., Wynn-Williams, D.D., 2002. Antarctic soil nematode response to artificial climate amelioration. European Journal of Soil Biology 38, 255-259.

410 Convey, P., Smith, R.I.L., 2006. Responses of terrestrial Antarctic ecosystems to climate change. Plant Ecology 182, 1-10.

Davey, M.C., Rothery, P., 1992. Factors causing the limitation of growth of terrestrial algae in Maritime Antarctica during late summer. Polar Biology 12, 595-601.

415 Dennis, P.G., Rushton, S.P., Newsham, K.K., Lauducina, V.A., Ord, V.J., Daniell, T.J., O’Donnell, A.G., Hopkins, D.W., 2012. Soil fungal community composition does not alter along a latitudinal gradient through the maritime and sub-Antarctic. Fungal Ecology, in press. 
Deslippe, J.R., Hartmann, M., Mohn, W.W., Simard, S.W., 2011. Long-term experimental 420 manipulation of climate alters the ectomycorrhizal community of Betula nana in Arctic tundra. Global Change Biology 17, 1625-1636.

Drijber, R.A., Doran, J.W., Parkhurst, A.M., Lyon, D.J., 2000. Changes in soil microbial community structure with tillage under long-term wheat-fallow management. Soil Biology and Biochemistry 32, 1419-1430.

Fowbert, J.A., Smith, R.I.L., 1994. Rapid population increases in native vascular plants in the Argentine Islands, Antarctic Peninsula. Arctic and Alpine Research 26, 290-296.

430 Haack, S.K., Garchow, H., Odelson, D.A., Forney, L.J., Klug, M.J., 1994. Accuracy, reproducibility and interpretation of fatty acid methyl ester profiles of model bacterial communities. Applied and Environmental Microbiology 60, 2483-2493.

Hansen, J., Sato, M., Reudy, R., Lo, K., Lea, D.W., Medina-Elizade, M., 2006. Global 435 temperature change. Proceedings of the National Academy of Sciences of the USA 103, 14288-14293.

Harris, J.M., Tibbles, B.J., 1997. Factors affecting bacterial productivity in soils on isolated inland nunataks in continental Antarctica. Microbial Ecology 33, 106-123.

440 Hill, P.W., Farrar, J., Roberts, P., Farrell, M., Grant, H., Newsham, K.K., Hopkins, D.W., Bardgett, R.D., Jones, D.L., 2011. Vascular plant success in a warming Antarctic may be due to efficient nitrogen acquisition. Nature Climate Change 1, 50-53. 
Hinojosa, M.B., Carreira, J.A., Garcia-Ruız, R., Dick, R.P., 2005. Microbial response to heavy metal-polluted soils: community analysis from phospholipids-linked fatty acids and ester-linked fatty acids extracts. Journal of Environmental Quality 34, 1789-1800.

Hopkins, D.W., Sparrow, A.D., Novis, P.M., Gregorich, E.G., Elberling, B., Greenfield, L.G., 2006a. Controls on the distribution of productivity and organic resources in Antarctic dry valley soils. Proceedings of the Royal Society of London B - Biological Sciences 273, 2687 2695

Hopkins, D.W., Sparrow, A.D., Elberling, B., Gregorich, E.G., Novis, P.M., Greenfield, L.G., Tilson, E.L., 2006b. Carbon, nitrogen and temperature controls on microbial activity in soils from an Antarctic dry valley. Soil Biology and Biochemistry 38, 3130-3140.

Hopkins, D.W., Sparrow, A.D., Shillam, L.L., English, L.C., Dennis, P.G., Novis, P.M, Elberling, B., Gregorich, E.G., Greenfield, L.G., 2008. Enzymatic activities and microbial communities in an Antarctic Dry Valley soil: responses to C and N supplementation. Soil 460 Biology and Biochemistry 40, 2130-2136.

Kieft, T.L., Ringelberg, D.B., White, D.C., 1994. Changes in ester-linked phospholipid fatty acid profiles of subsurface bacteria during starvation and desiccation in a porous medium. Applied and Environmental Microbiology 60, 3292-3299.

465 Lechevalier, H., Lechevalier, M.P., 1988. Chemotaxonomic use of lipids - an overview. In: Ratledge, C., Wilkinson, S.G. (Eds.), Microbial Lipids. Academic Press, London, pp. 869902. 
Marion, G.M., Henry, G.H.R., Freckman, D.W., Johnstone, J., Jones, G., Jones, M.H., Le

470 Vesques, E., Molau, U., Mølgaard, P., Parsons, A.N., Svoboda, J., Virginia, R.A., 1997.

Open-top designs for manipulating field temperature in high-latitude ecosystems. Global Change Biology 3, 20-32.

Malosso, E., English, L., Hopkins, D.W., O’Donnell, A.G., 2005. Community level physiological profile response to plant residue additions in Antarctic soils. Biology and Fertility of Soils 42, 60-65.

Mikan, C.J., Schimel, J.P., Doyle, A.P., 2002. Temperature controls of microbial respiration in arctic tundra soils above and below freezing. Soil Biology and Biochemistry 34, 1785480 1795.

Newsham, K.K., Pearce, D.A., Bridge, P.D., 2010. Minimal influence of water and nutrient content on the bacterial community composition of a maritime Antarctic soil. Microbiological Research 165, 523-530.

Novis, P.M., Whitehead, D.C., Gregorich, E.G., Hunt, J.E., Sparrow, A.D., Hopkins, D.W., Elberling, B., Greenfield, L.G., 2007. Annual carbon fixation in terrestrial populations of Nostoc commune (Cyanobacteria) from an Antarctic dry valley is driven by temperature regime. Global Change Biology 13, 1224-1237.

490 O’Leary, W.M., Wilkinson, S.G., 1988. Gram-positive bacteria. In: Ratledge, C., Wilkinson, S.G. (Eds.), Microbial Lipids. Academic Press, London, pp. 117-202. 
Quayle, W.C., Peck, L.S., Peat, H.J., Ellis-Evans, J.C., Harrigan, P.R., 2002. Extreme responses to climate change in Antarctic lakes. Science 295, 645.

495

Rinnan, R., Michelsen, A., Bååth, E., Jonasson, S., 2007. Fifteen years of climate change manipulations alter soil microbial communities in a subarctic heath ecosystem. Global Change Biology 13, 28-39.

500 Russell, N.J., 1990. Cold adaptation of microorganisms. Philosophical Transactions of the Royal Society of London B 326, 595-611.

Schimel, J., Balser, T.C., Wallenstein, M., 2007. Microbial stress-response physiology and its implications for ecosystem function. Ecology 88, 1386-1394.

505

Schmidt, I.K., Ruess, L., Bååth, E., Michelsen, A., Ekelund, F., Jonasson, S., 2000. Longterm manipulations of the microbes and microfauna of two subarctic heaths by addition of fungicide, bacteriocide, carbon and fertilizer. Soil Biology and Biochemistry 32, 707-720.

510 Schutter, M.E., Dick, R.P., 2000. Comparison of fatty acid methyl ester (FAME) methods for characterizing microbial communities. Soil Science Society of America Journal 64, 16591668.

Shaver, G.R., Bret-Harte, M.S., Jones, M.H., Johnstone, J., Gough, L., Laundre, J., Chapin 515 III, F.S., 2001. Species composition interacts with fertilizer to control long-term change in tundra productivity. Ecology 82, 3163-3181. 
Simmons, B.L., Wall, D.H., Adams, B.J., Ayres, E., Barrett, J.E., Virginia, R.A., 2009. Longterm experimental warming reduces soil nematode populations in the McMurdo Dry Valleys, Antarctica. Soil Biology and Biochemistry 41, 2052-2060.

Smith, J.J., Tow, L.A., Stafford, W., Cary, C., Cowan, D.A., 2006. Bacterial diversity in three different Antarctic cold desert mineral soils. Microbial Ecology 51, 413-421.

525 Smith, R.I.L., 1984. Terrestrial plant biology of the sub-Antarctic and Antarctic. In: Laws, R.M. (Ed.), Antarctic Ecology vol 1. Academic Press, London, pp. 61-162.

Smith, R.I.L., 1994. Vascular plants as bioindicators of regional warming in Antarctica. Oecologia 99, 322-328.

530

Sparrow, A.D., Gregorich, E.G., Hopkins, D.W., Novis, P.M., Elberling, B., Greenfield, L.G., 2011. Resource limitations on the activity of a soil microbial community in the dry valleys of southern Victoria Land, Antarctica. Soil Science Society of America Journal 75, $2188-2197$.

535

Steger, K., Jarvis, A., Smars, S., Sundh, I., 2003. Comparison of signature lipid methods to determine microbial community structure in compost. Journal of Microbiological Methods $55,371-382$.

540 Sugden, D.E., Clapperton, C.M., 1981. An ice-shelf moraine, George VI Sound, Antarctica. Annals of Glaciology 2, 135-141. 
Thomas, E.R., Marshall, G.J., McConnell, J.R., 2008. A doubling in snow accumulation in the western Antarctic Peninsula since 1850. Geophysical Research Letters 35, L01706.

Thomas, E.R., Dennis, P.F., Bracegirdle, T.J., Franzke, C., 2009. Ice core evidence for significant 100-year regional warming on the Antarctic Peninsula. Geophysical Research Letters 36, L20704.

Walker, M.D., Wahren, C.H., Hollister, R.D., Henry, G.H.R., Ahlquist, L.E., Alatalo, J.M., Bret-Harte, M.S., Calef, M.P., Callaghan, T.V., Carroll, A.B., Epstein, H.E., Jónsdóttir, I.S., Klein, J.A., Magnússon, B., Molau, U., Oberbauer, S.F., Rewa, S.P., Robinson, C.H., Shaver, G.R., Suding, K.N., Thompson, C.C., Tolvanen, A., Totland, Ø., Turner, P.L., Tweedie, C.E., Webber, P.J., Wookey, P.A., 2006. Plant community responses to experimental warming across the tundra biome. Proceedings of the National Academy of Sciences of the USA 103, $1342-1346$.

Wookey, P.A., Aerts, R., Bardgett, R.D., Baptist, F., Bråthen, K.A., Cornelissen, J.H.C., Gough, L., Hartley, I.P., Hopkins, D.W., Lavorel, S., Shaver, G.R., 2009. Ecosystem feedbacks and cascade processes: understanding their role in the responses of arctic and alpine ecosystems to environmental change. Global Change Biology 15, 1153-1172.

Wynn-Willams, D.D., 1996. Response of pioneer soil microalgal colonists to environmental change in Antarctica. Microbial Ecology 31, 177-188.

565 Yergeau, E., Bokhorst, S., Huiskes, A.H.L., Boschker, H.T.S., Aerts, R., Kowalchuk, G.A., 2007a. Size and structure of bacterial, fungal and nematode communities along an Antarctic environmental gradient. FEMS Microbiology Ecology 59, 436-451. 
Yergeau, E., Newsham, K.K., Pearce, D.A., Kowalchuk, G.A., 2007b. Patterns of bacterial 570 diversity across a range of Antarctic terrestrial habitats. Environmental Microbiology 9, 2670-2682.

Yergeau, E., Bokhorst, S., Kang, S., Zhou, J., Greer, C.W., Aerts, R., Kowalchuk, G.A., 2012. Shifts in soil microorganisms in response to warming are consistent across a range of 575 Antarctic environments. The ISME Journal, in press.

Zak, D.R., Holmes, W.E., MacDonald, N.W., Pregitzer, K.S., 1999. Soil temperature, matric potential, and the kinetics of microbial respiration and nitrogen mineralization. Soil Science of America Journal 63, 575-584.

580

Zelles, L., 1999. Fatty acid patterns of phospholipids and lipopolysaccharides in the characterisation of microbial communities in soil, a review. Biology and Fertility of Soils 29, 111-129. 


\section{Table 1}

$F$ ratios from general linear models testing for the main and interactive effects of substrate amendments, water application and OTCs on the concentrations of Gram positive and Gram negative bacterial markers, and the ratio of Gram positive to Gram negative markers, at Wynn Knolls and Mars Oasis. Significant values are denoted by $* P<0.05$, $* * P<0.01$ and $590 * * * P<0.001$. Error d.f. in all analyses were 48.

\begin{tabular}{|c|c|c|c|c|c|c|}
\hline \multirow[b]{2}{*}{ Wynn Knolls } & \multicolumn{2}{|c|}{ Gram positive } & \multicolumn{2}{|c|}{ Gram negative } & \multicolumn{2}{|c|}{$\begin{array}{c}\text { Gram positive / Gram } \\
\text { negative ratio }\end{array}$} \\
\hline & & & & & & \\
\hline Substrate & 8.20 & $* * *$ & 6.15 & $* *$ & 2.62 & \\
\hline Water & 0.06 & & 1.63 & & 0.92 & \\
\hline OTC & 0.12 & & 1.19 & & 0.23 & \\
\hline Substrate $\times$ water & 0.73 & & 1.29 & & 0.11 & \\
\hline Substrate $\times$ OTC & 1.42 & & 0.87 & & 0.33 & \\
\hline Water $\times$ OTC & 0.53 & & 1.03 & & 0.36 & \\
\hline Substrate $\times$ water $\times$ OTC & 0.92 & & 0.99 & & 1.39 & \\
\hline \multicolumn{7}{|l|}{ Mars Oasis } \\
\hline Substrate & 8.76 & $* * *$ & 2.05 & & 11.91 & $* * *$ \\
\hline Water & 0.52 & & 1.18 & & 0.14 & \\
\hline OTC & 11.81 & $* *$ & 0.05 & & 17.45 & $* * *$ \\
\hline Substrate $\times$ water & 0.61 & & 1.09 & & 0.54 & \\
\hline Substrate $\times$ OTC & 2.94 & $*$ & 0.45 & & 5.97 & $* *$ \\
\hline Water $\times$ OTC & 0.51 & & 0.44 & & 0.11 & \\
\hline Substrate $\times$ water $\times$ OTC & 0.58 & & 1.97 & & 0.29 & \\
\hline
\end{tabular}




\section{Figure legends}

595 Fig. 1. Map of the maritime Antarctic, indicating the locations of Signy Island, Alexander Island and Mars Oasis.

Fig. 2. Mean monthly soil temperatures (left axis) in control plots (open bars) and plots covered with OTCs (closed bars) at (a) Wynn Knolls and (b) Mars Oasis. Values are means of three replicates + SEM. Significant differences between those for control and chambered plots are denoted by $* ; P<0.05$. The dashed line shows the difference in temperature between control and chambered plots (right axis).

Fig. 3. Concentrations of (a) Gram positive and (b) Gram negative markers, and (c) the ratio between Gram positive and Gram negative markers, at Wynn Knolls and Mars Oasis. Values are means of 64 replicates + SEM. Significant differences between sites are denoted by ***; $P<0.001$. Note that the $y$-axis in (c) is dimensionless.

Fig. 4. The influence of glucose, glycine and TSB application to soil on the concentrations of

610 Gram positive (a, d) and Gram negative (b, e) markers, and the ratio of Gram positive to Gram negative markers (c, f), at Wynn Knolls (left column) and Mars Oasis (right column). Values are means of 16 replicates + SEM. Those that are significantly different from controls are denoted by $* ; P<0.05, * * ; P<0.01$ and $* * * ; P<0.001$. Note that the $y$-axes in (c) and (f) are dimensionless. Insets in (a) and (d) show the concentrations of the markers a15:0 and

615 a17:0 in non-amended soil (con) or soil to which glycine (gly) or TSB had been applied at Wynn Knolls and Mars Oasis, respectively. That in (b) shows the concentration of $16: 1 \omega 7 \mathrm{c}$ in non-amended (con) soil or soil to which TSB had been applied at Wynn Knolls. Notation as in main figures. 
Fig. 5. Mean concentrations of Gram positive markers (left column) and the ratio of Gram 620 positive to Gram negative markers (right column) at Mars Oasis in control soils (open bars) and soils covered with OTCs (closed bars) that were either non-amended (a, e) or to which glucose $(b, f)$, glycine $(c, g)$ or TSB $(d, h)$ had been applied. Values are means of eight replicates + SEM. Those that are significantly different from controls are denoted by *; $P<0.05$ and $* * ; P<0.01$. Note that the $y$-axes in (e)-(h) are dimensionless. Insets in (c) and (d) show the concentrations of the markers a15:0 and a17:0 in control (con) or chambered (OTC) soil to which glycine or TSB had been applied, respectively. Notation as in main figures. 


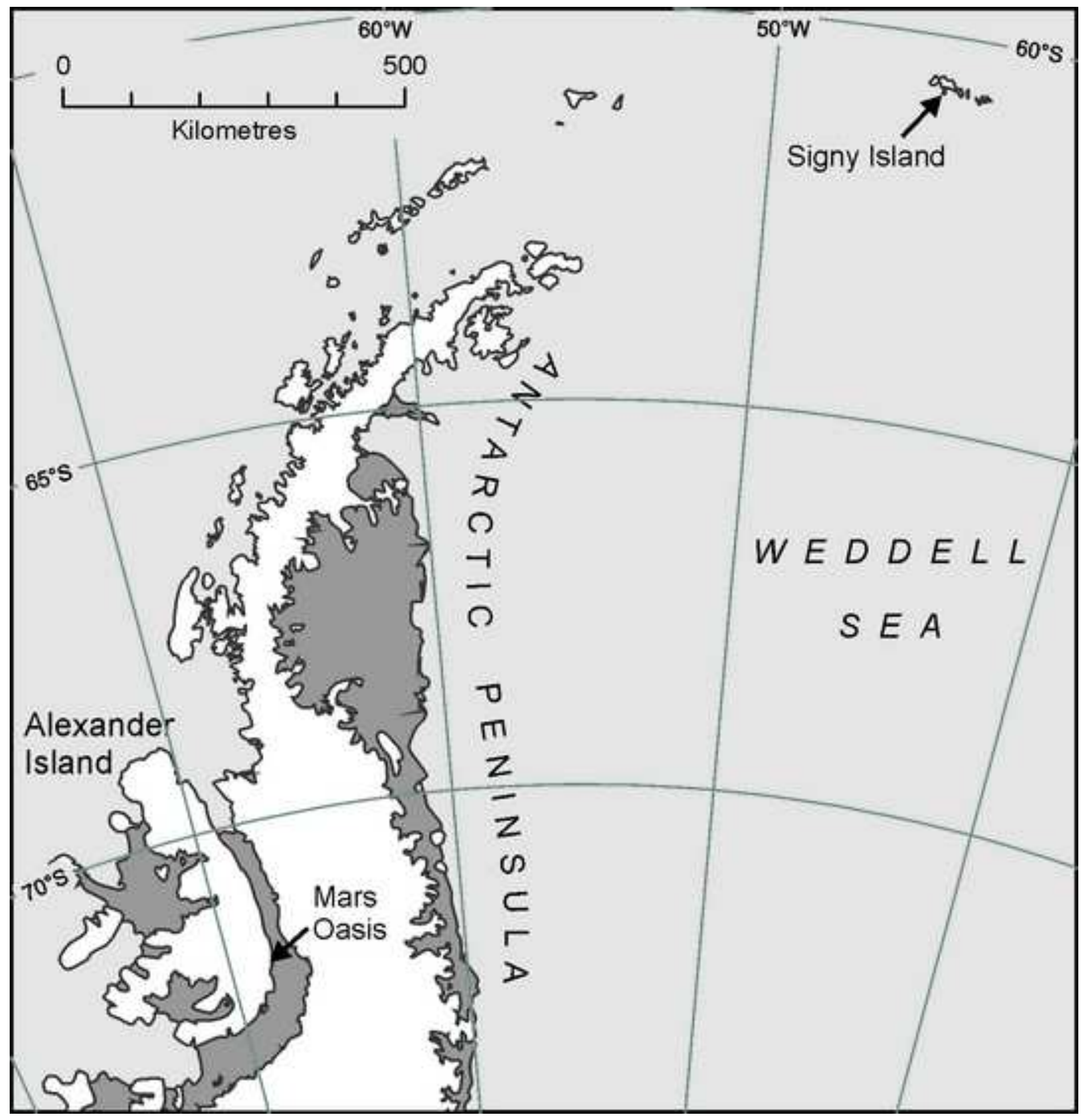


Figure
Click here to download high resolution image

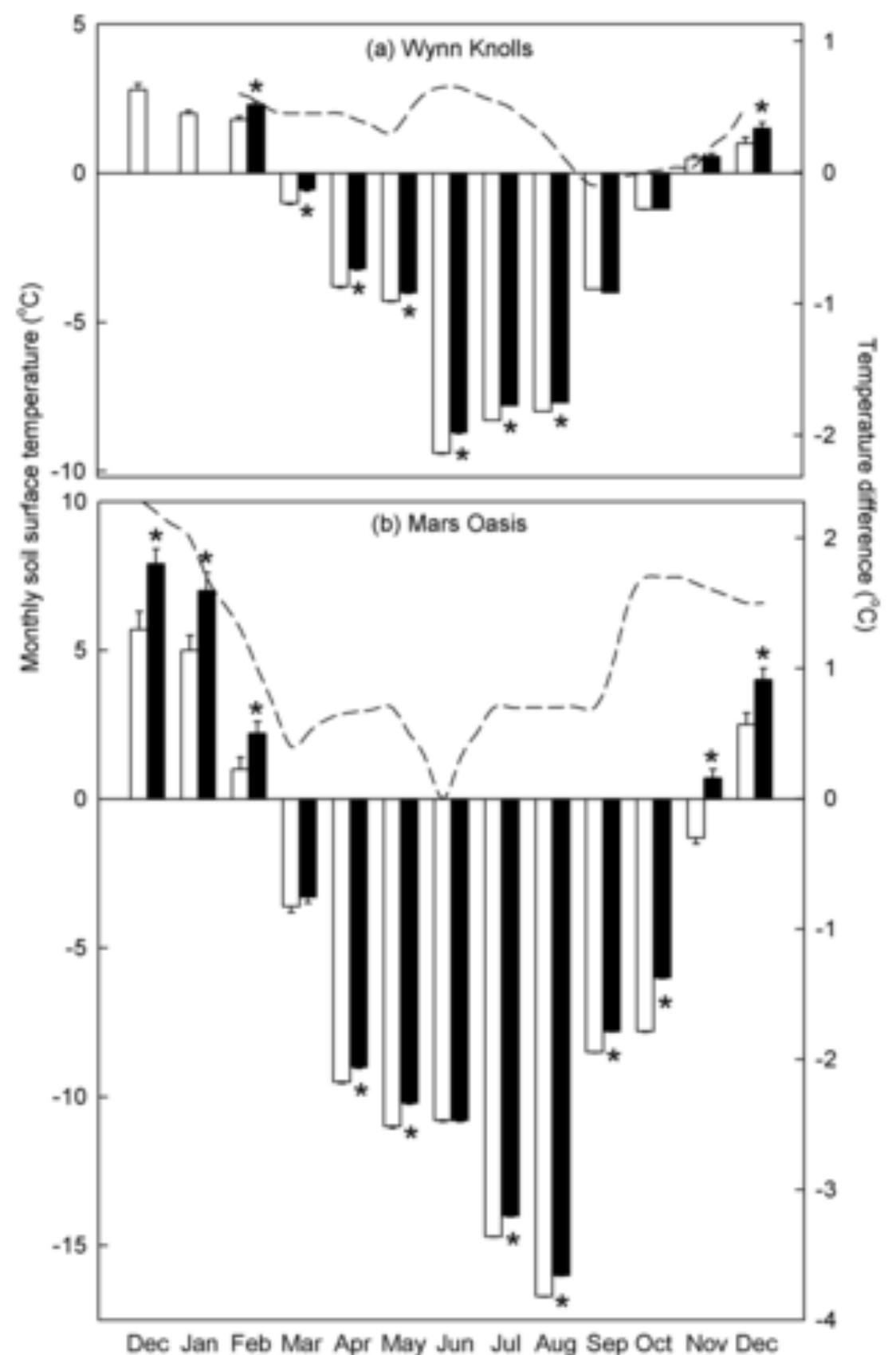

Jan Feb Mar Apr May Jun 
Figure
Click here to download high resolution image
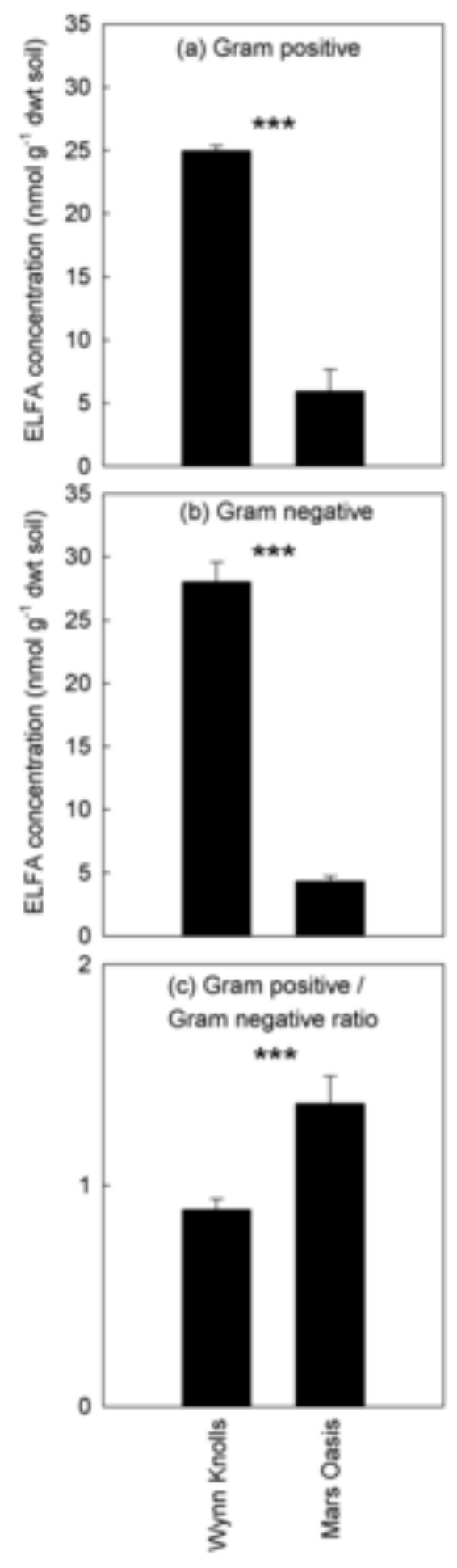
Click here to download high resolution image
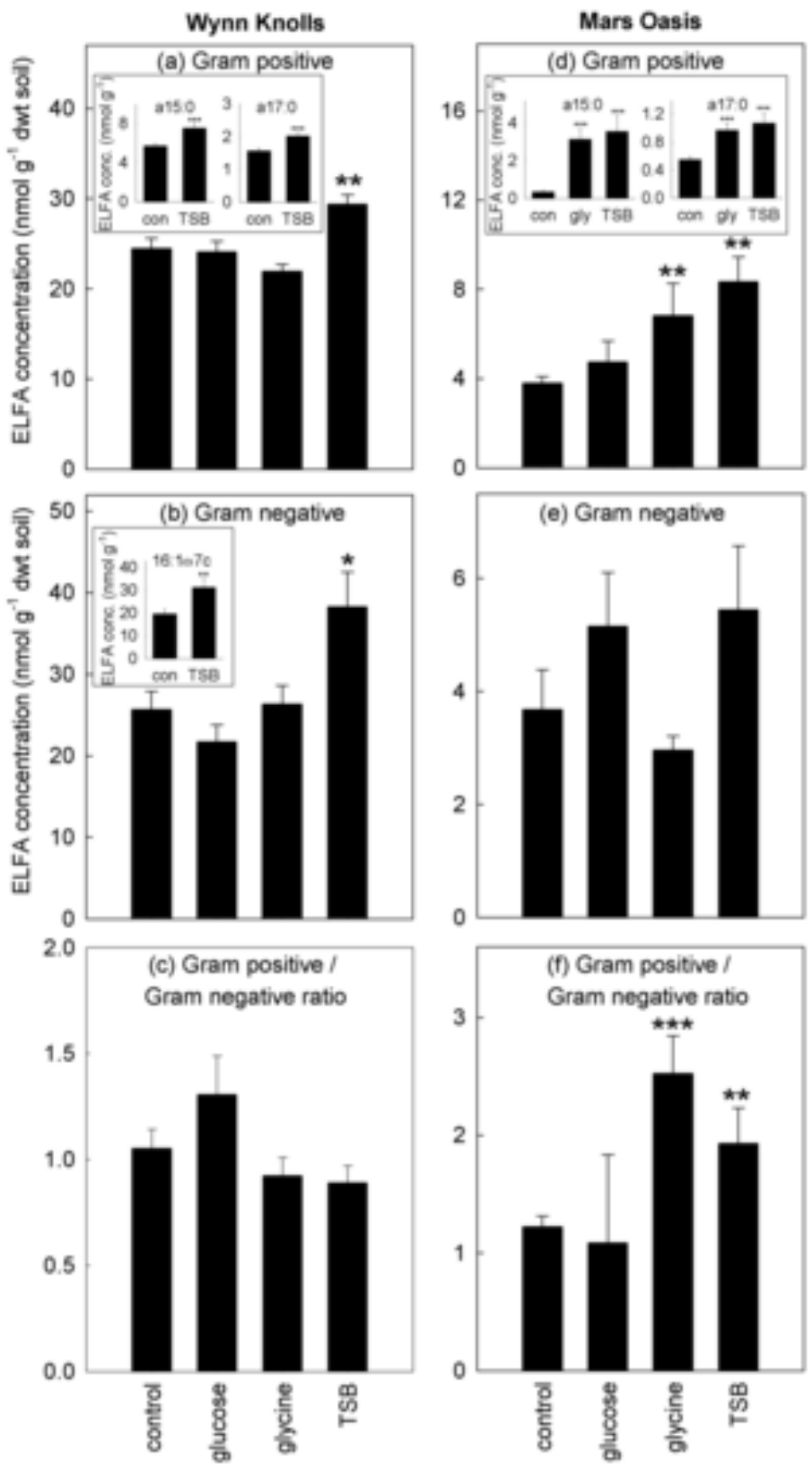
Click here to download high resolution image

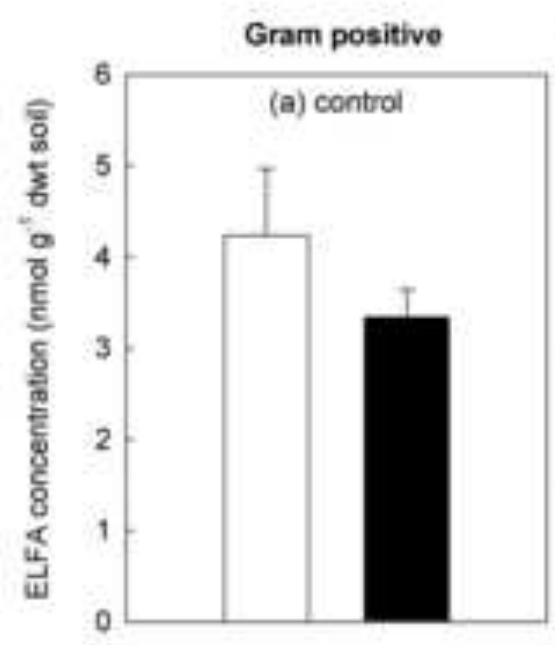

Gram positive / Gram negative ratio
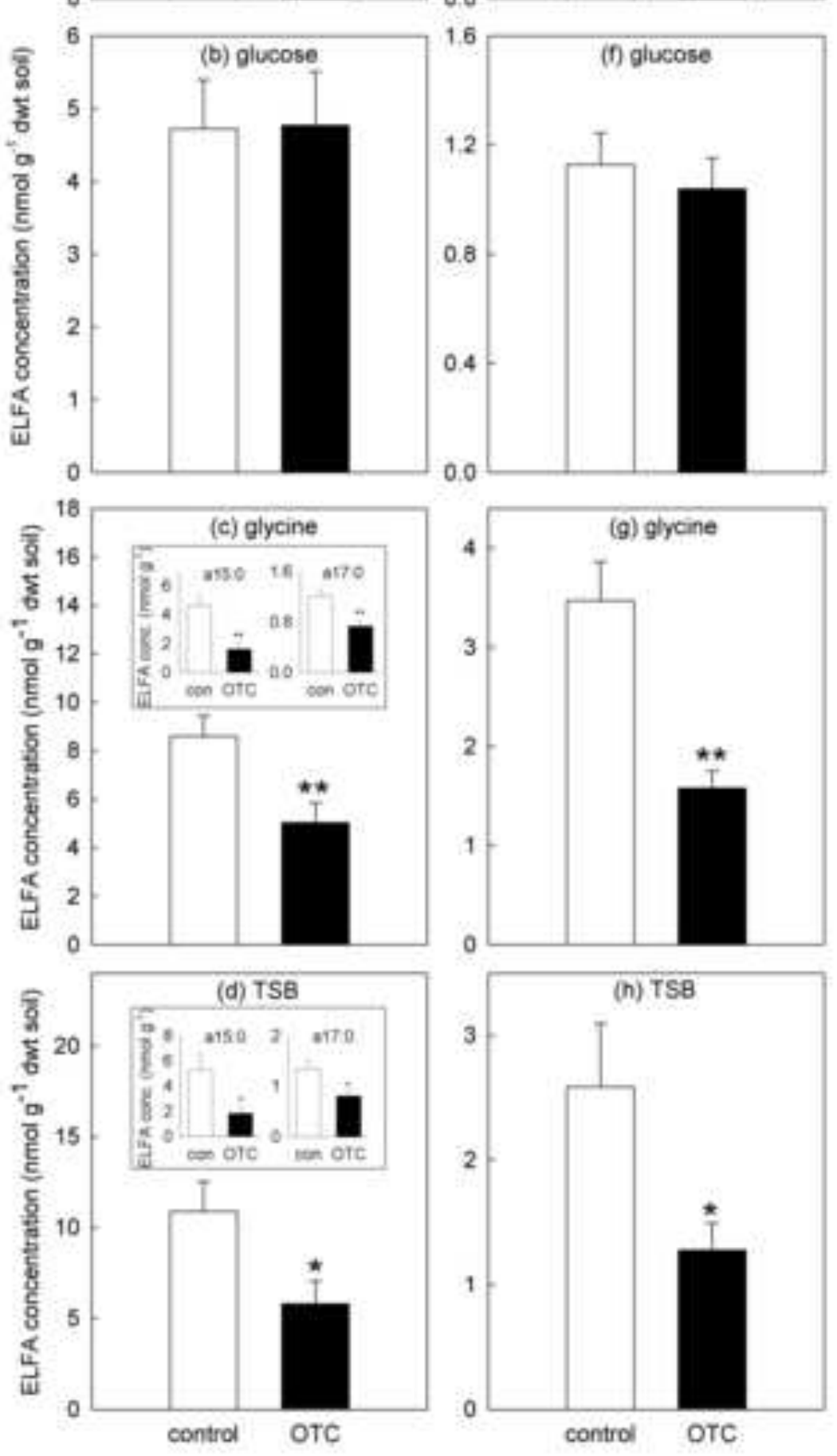

(e) control

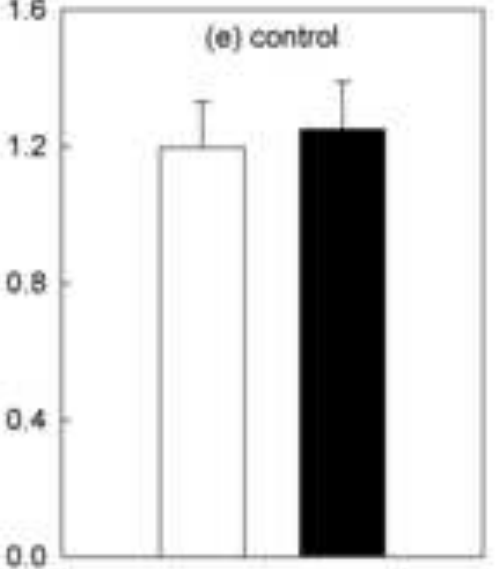

